\title{
Research on the Green Competitiveness Index of Manufacturing Industry in Yangtze River Delta Urban Agglomeration
}

\section{Badanie wskaźnika zielonej konkurencyjności przemysłu wytwórczego w aglomeracji miejskiej delty rzeki Jangcy}

\author{
Yuhong Cao*, Jianxin You", Yongjiang Shi ${ }^{\star \star \star}$,Wei Hu${ }^{\star \star \star \star}$ \\ *School of Management, Shanghai University, Shanghai,200444,China \\ **School of Economics \&Management, Tongji University, Shanghai, 200092, China \\ ***Institute for Manufacturing, University of Cambridge, CB3 OFS Cambridge, UK \\ ****School of Economics and Trade, Shanghai Urban Construction Vocational College, \\ Shanghai, 201999, China (Corresponding Author) \\ E-mail:335021552@qq.com
}

\begin{abstract}
From the perspective of the complex multi-factors that affect manufacturing green competitiveness, this study constructs a green competitiveness index measurement indicator system of manufacturing industry in Yangtze River Delta Urban Agglomeration, which includes five dimensions: economic creativity, technological innovation, energy and environmental protection, industrial structure optimization, and social service capabilities. The manufacturing green competitiveness index in Yangtze River Delta Urban Agglomeration in 2014-2018 is measured and analyzed by using the comprehensive evaluation model of gray correlation projection method based on the combined weights of FAHP and maximum deviation. The results show that manufacturing green competitiveness of Yangtze River Delta Urban Agglomeration generally shows a relatively stable and continuous improvement trend, but the regional differences are large: regional cities and general node cities have significantly lower manufacturing green competitiveness than the leading cities and hub cities, and the pace of industrial structure transformation and upgrading in the whole region also needs to be accelerated. Based on these results, this paper puts forward some policy recommendations for comprehensive development of Yangtze River Delta Urban Agglomeration manufacturing industry: focus on improving the effective guidance of the positive incentive effect of technological innovation on manufacturing green competitiveness level, and solving the problem of insufficient technological innovation achievement transformation benefits; replan regional space, strengthen the integration of all industrial resources, reducing homogeneous competition; strengthen the ecological co-construction of regional manufacturing and improve social service security level.
\end{abstract}

Key words: Yangtze River Delta Urban Agglomeration, manufacturing green competitiveness, FAHP, maximum deviation, gray correlation projection method

\section{Streszczenie}

Z perspektywy złożonych czynników, które wpływają na konkurencyjność ekologiczną produkcji, w niniejszym artykule opracowano system pomiaru wskaźnika konkurencyjności ekologicznej dla przemysłu wytwórczego w aglomeracji miejskiej w delcie rzeki Jangcy. Obejmuje on pięć wymiarów: kreatywność ekonomiczną, innowacje technologiczne, energię i ochronę środowiska, optymalizację struktury przemysłowej i zakres usług społecznych. Wskaźnik konkurencyjności ekologicznej produkcji w aglomeracji miejskiej delty rzeki Jangcy w latach 20142018 jest mierzony i analizowany za pomocą kompleksowego modelu oceny metodą projekcji szarej korelacji opartej na połączonych wagach FAHP i maksymalnym odchyleniu. Wyniki pokazują, że konkurencyjność pro- 
dukcji ekologicznej w aglomeracji miejskiej delty rzeki Jangcy na ogół wykazuje względnie stabilną i ciągłą tendencję do poprawy, ale różnice regionalne są duże: miasta regionalne i główne miasta węzłowe mają znacznie niższą konkurencyjność ekologiczną w zakresie produkcji niż miasta wiodące i miasta centralne, a tempo transformacji i modernizacji struktury przemysłowej w całym regionie również wymaga przyspieszenia. W oparciu o te wyniki, w niniejszym artykule przedstawiono pewne zalecenia polityczne dotyczące wszechstronnego rozwoju przemysłu wytwórczego w aglomeracji miejskiej delty rzeki Jangcy: skupiono się na sformułowaniu skutecznych wskazówek dotyczących pozytywnego efektu zachęty ze strony innowacji technologicznych na poziom konkurencyjności produkcji ekologicznej oraz na rozwiązaniu problemu niewystarczającej korzyści z transformacji osiągnięć innowacji technologicznych; należy przebudować przestrzeń regionalną, wzmocnić integrację wszystkich zasobów przemysłowych, zmniejszając jednorodną konkurencję; wzmocnić ekologiczne współtworzenie regionalnej produkcji i poprawić poziom zabezpieczenia społecznego.

Słowa kluczowe: aglomeracja miejska w delcie rzeki Jangcy, ekologiczna konkurencyjność produkcji, FAHP, maksymalne odchylenie, metoda projekcji korelacji szarości

\section{Introduction}

In 2014, the State Council's Guiding Opinions on Promoting the Development of the Yangtze River Economic Belt by Golden Water Channels set clear and specific requirements for the positioning and functions of Yangtze River Delta Urban Agglomeration: develop a new economy and implement an innovation-driven development strategy; create a good ecological environment and implement ecological construction and restoration; become a world-class city group with global influence by 2030. In 2018, the economic aggregate of Yangtze River Delta Urban Agglomerations accounted for about 20\% China's total GDP, which was about 17.8 trillion yuan, with a growth rate of $7.14 \%$, higher than the average growth rate of $6.6 \%$ of China's GDP. Among the various urban agglomerations that have been formed in China, Yangtze River Delta Urban Agglomeration is currently the highest level of economic agglomeration in China.

The construction of Yangtze River Delta Urban Agglomeration is inseparable from the development of manufacturing industry, which is the pillar industry of Yangtze River Delta. In 2018, the added value of manufacturing industry in this region accounted for $20.4 \%$ of the national added value. The manufacturing industry is developed, and the specialized production mode brings the continuous deepening of industrial agglomeration. From 2008 to 2018, the agglomeration degree of manufacturing industry in Yangtze River Delta Urban Agglomeration was greater than 1 , which was generally higher than the national average (the national average is 0.87 ). The high concentration of manufacturing industry, as well as the traditional development mode of Chinese manufacturing with high investment and high pollution, lead to manufacturing environment in Yangtze River Delta Urban Agglomeration is not optimistic. For example, in 2018, the average concentration of PM2.5 in 26 cities in Yangtze River Delta Urban Agglomeration was $44 \mu \mathrm{g} / \mathrm{m}^{3}$, at the same time, it was only $15 \mu \mathrm{g} / \mathrm{m}^{3}$ in San Francisco, $10 \mu \mathrm{g} / \mathrm{m}^{3}$ in New York and $13 \mu \mathrm{g} / \mathrm{m}^{3}$ in Tokyo. Another example is energy consumption. The secondary industry in
Yangtze River Delta Urban Agglomeration must use $73.14 \%$ energy consumption to contribute $50.13 \%$ GDP. In the past five years, the energy consumption of per 10,000 US dollars GDP in the United States, Japan, and South Korea was 1.64, 1.05, and $2.47 \mathrm{t}$ standard oil, the energy consumption of per 10,000 US dollars GDP in Singapore, Hong Kong and Taiwan provinces is $3.28,1.2$ and $2.81 \mathrm{t}$ standard oil, while the energy consumption of per 10,000 US dollars GDP in Yangtze River Delta Urban Agglomeration is $3.50 \mathrm{t}$ standard oil. Improving manufacturing green competitiveness will help alleviate the environmental pressures faced by Yangtze River Delta Urban Agglomeration, and will also help resolve conflicts between the goals of different administrative, economic, and social subjects in the integrated development of Yangtze River Delta, it is of great significance for Yangtze River Delta urban agglomeration to become a world-class urban agglomeration.

Since the hypothesis of Environmental Kuznets curve (EKC) was put forward, green competitiveness has attracted the attention of scholars. At present, the research on manufacturing green competitiveness mainly includes the following aspects: connotation and its differences from basic competitiveness, industrial competitiveness, enterprise competitiveness, and technological competitiveness (Porter, 1995; Jon Plaut, 1998; Wang, 2010; Chen, 2012); the importance of environmental accounting system for economic development (Guerrieri, 2005; Zhu \& Sun, 2012; Guan, 2016); construction of green industry system framework (Bill, 2002; Li \& Yang, 2014; Yang, 2016); pattern design (Vaccaro, 2010; Shao, 2012; Hou, 2015; Zhou, 2015).Few studies have focused on the evaluation of manufacturing green competitiveness, only Martins (2007), Li (2010), Li\&Yang (2014) have discussed the influencing factors of manufacturing green competitiveness.

Due to intensified resource constraints, manufacturing industry in Yangtze River Delta Urban Agglomeration began to transfer to the outside, especially to the central and western regions, which caused the adjustment of manufacturing space layout, the fluctuation of regional economic development, and the hin- 
drance of the subsequent manufacturing development. Low carbon development and green technology have become the direction of manufacturing sustainable development, which is the premise and foundation of Yangtze River Delta integrated development, as important as innovative manufacturing and intelligent manufacturing. Based on this, this paper takes the manufacturing industry of Yangtze River Delta Urban Agglomeration as the research object, first constructs the manufacturing green competitiveness index measurement index system in accordance with the requirements of industrial green development plan, which includes five dimensions: the ability of economic creation, the ability of scientific and technological innovation, the ability of energy and environmental protection, the ability of industrial structure optimization and the ability of social services, then use a grey correlation projection comprehensive evaluation model based on FAHPdispersion maximization combined weighting to measure and analyze Yangtze River Delta Urban Agglomeration manufacturing green competitiveness from 2014 to 2018 . This study overcomes the limitations of current related research on manufacturing green competitiveness, which only focuses on qualitative assessment and the competitiveness factors only focus on economic creativity. Through the calculation of manufacturing green competitiveness index, the key factors affecting manufacturing green competitiveness in Yangtze River Delta Urban Agglomeration are identified, which provides a theoretical basis for formulating a path for improving Yangtze River Delta Urban Agglomeration manufacturing competitiveness.

The structure of this paper is as follows. The second part, evaluation model is constructed, green competitiveness index measurement indicator system is established through research and expert interviews, and the measurement method is selected. The third part, calculated and analysis Yangtze River Delta Urban Agglomeration manufacturing green competitiveness index. The fourth part, conclusion and suggestion, competitiveness promotion strategy formulation and policy enlightenment proposal.

\section{Evaluation index system setting}

The regional manufacturing green competitiveness is based on the regional perspective, which not only covers the basic characterization of regional manufacturing economic growth, but also closely related to many factors such as resources, environment and society. Based on the development of manufacturing industry and the current situation of its resources and ecological environment in Yangtze River Delta Urban Agglomeration, taking sustainable development, scientificity, systematization, continuity, comparability and data availability as the basic principle, referring to the evaluation ideas of Martins (2007), Li(2010), Li\&Yang (2014), this paper constructs
Yangtze River Delta Urban Agglomerations manufacturing green competitiveness evaluation index from five dimensions and 29 indicators, the specific evaluation dimensions and indicators are shown in Table 1.

The dimension of economic creativity. Economic creation is the focus of green competitiveness in regional manufacturing. It is not only the premise of maintaining Yangtze River Delta Urban Agglomeration manufacturing vitality, but also the basis of building green competitiveness. Among them, the total output value of manufacturing industry and its proportion in the industrial output are used to reflect manufacturing output level and its contribution to the national economy, and also can reflect the overall manufacturing industry development scale in Yangtze River Delta Urban Agglomeration. The product sales rate reflects the supply of manufacturing products and the extent to which they meet social needs. Enterprise unit output value and total corporate profit are used to reflect the profitability of manufacturing enterprises. Profit acquisition capability is a direct reflection of Yangtze River Delta Urban Agglomeration manufacturing industry development performance, the stronger the capability, the higher the potential for improving green competitiveness.

The dimension of scientific and technological innovation capabilities. Scientific and technological innovation is an important means for Yangtze River Delta Urban Agglomeration to become a global advanced manufacturing center and an important international gateway in the Asia-Pacific region, as well as a key way for Yangtze River Delta Urban Agglomeration to become a highland of scientific and technological innovation with global influence. Among them, R\&D expenditure, R\&D personnel full-time equivalent, and $R \& D$ input intensity are manufacturing R\&D indicators, which are used to reflect the expenditure intensity of manufacturing R\&D activities in Yangtze River Delta Urban Agglomeration. R\&D personnel proportion is used to reflect manufacturing $R \& D$ potential, and the four indicators are all important contents to reflect the manufacturing independent innovation ability and green competition potential. The number of new product development projects and new product development expenditure are product development indicators, which are used to reflect the strength of manufacturing investment in new product development, and can also reflect the degree to which the manufacturing industry grasps the market demand. The number of patents is a patent indicator, which is used to reflect the output of scientific and technological innovation activities of manufacturing industry, and also reflects the attention paid by manufacturing to technological protection. The output rate of new products is a reflection of manufacturing technology transformation and technology application capabilities, the transformation of technological achievements is a key link in fostering and shaping manu- 
Table 1. Evaluation indicator system of manufacturing green competitiveness index of Yangtze River Delta Urban Agglomeration

\begin{tabular}{|c|c|c|c|c|c|}
\hline Dimension & Indicators & Description & Unit & Property & Weights \\
\hline \multirow{5}{*}{$\begin{array}{l}\text { Economic cre- } \\
\text { ativity } \\
(0.2526)\end{array}$} & Total output value & Manufacturing output & $\begin{array}{c}100 \text { million } \\
\text { yuan }\end{array}$ & Positive & 0.0623 \\
\hline & $\begin{array}{l}\text { Proportion of total out- } \\
\text { put value to total in- } \\
\text { dustrial output value }\end{array}$ & $\begin{array}{l}\text { Manufacturing output/Industrial } \\
\text { output }\end{array}$ & $\%$ & Positive & 0.0582 \\
\hline & Product sales rate & $\begin{array}{l}\text { Manufacturing Product Sales } \\
\text { Revenue / Total Manufacturing } \\
\text { Output Value }\end{array}$ & $\%$ & Positive & 0.0341 \\
\hline & $\begin{array}{l}\text { Enterprise unit output } \\
\text { value }\end{array}$ & $\begin{array}{l}\text { Manufacturing output/ Number } \\
\text { of manufacturing enterprises }\end{array}$ & $\begin{array}{c}100 \text { million } \\
\text { yuan/ } \\
\text { individual }\end{array}$ & Positive & 0.0426 \\
\hline & Total corporate profits & $\begin{array}{l}\text { Sum of profits of all manufactur- } \\
\text { ing enterprises }\end{array}$ & $\begin{array}{c}100 \text { million } \\
\text { yuan }\end{array}$ & Positive & 0.0554 \\
\hline \multirow{10}{*}{$\begin{array}{c}\text { Scientific } \\
\text { and techno- } \\
\text { logical inno- } \\
\text { vation capa- } \\
\text { bilities } \\
(0.2432)\end{array}$} & R\&D expenditure & $\begin{array}{l}\text { Total R\&D expenditure of all } \\
\text { category } \mathrm{C} \text { manufacturing indus- } \\
\text { tries }\end{array}$ & $\begin{array}{l}100 \text { million } \\
\text { yuan }\end{array}$ & Positive & 0.0348 \\
\hline & $\begin{array}{l}\text { R\&D personnel full- } \\
\text { time equivalent }\end{array}$ & $\begin{array}{l}\text { Full time equivalent of R \& D } \\
\text { personnel in all category C Man- } \\
\text { ufacturing Industries }\end{array}$ & $\begin{array}{l}\text { Ten thou- } \\
\text { sand peo- } \\
\text { ple.year }\end{array}$ & Positive & 0.0204 \\
\hline & $\begin{array}{l}\text { R\&D investment inten- } \\
\text { sity }\end{array}$ & $\begin{array}{l}\text { Manufacturing R\&D Expendi- } \\
\text { ture / GDP of Yangtze River } \\
\text { Delta Urban Agglomeration } \\
\end{array}$ & $\%$ & Positive & 0.0312 \\
\hline & $\begin{array}{l}\text { Proportion of R\&D } \\
\text { personnel }\end{array}$ & R\&D staff/ employees & $\%$ & Positive & 0.0365 \\
\hline & $\begin{array}{l}\text { Number of new prod- } \\
\text { uct development pro- } \\
\text { jects }\end{array}$ & $\begin{array}{l}\text { Number of new product develop- } \\
\text { ment projects in all category C } \\
\text { Manufacturing Industries }\end{array}$ & Item & Positive & 0.0296 \\
\hline & $\begin{array}{l}\text { New product deve- } \\
\text { lopment funds }\end{array}$ & $\begin{array}{l}\text { All new product development } \\
\text { funds of category } \mathrm{C} \text { manufactur- } \\
\text { ing industry }\end{array}$ & $\begin{array}{l}100 \text { million } \\
\text { yuan }\end{array}$ & Positive & 0.0224 \\
\hline & Number of patents & $\begin{array}{l}\text { Number of category } \mathrm{C} \text { manufac- } \\
\text { turing industry patents }\end{array}$ & Item & Positive & 0.0236 \\
\hline & $\begin{array}{l}\text { New product output } \\
\text { rate }\end{array}$ & $\begin{array}{l}\text { Manufacturing new product out- } \\
\text { put value / Total manufacturing } \\
\text { output value } \square\end{array}$ & $\%$ & Positive & 0.0144 \\
\hline & $\begin{array}{l}\text { Technology introduc- } \\
\text { tion funds }\end{array}$ & $\begin{array}{l}\text { Total cost of technology intro- } \\
\text { duction }\end{array}$ & $\begin{array}{l}100 \text { million } \\
\text { yuan }\end{array}$ & Positive & 0.0121 \\
\hline & $\begin{array}{l}\text { Funds for digestion } \\
\text { and absorption tech- } \\
\text { nology }\end{array}$ & $\begin{array}{l}\text { Total cost of digestion and ab- } \\
\text { sorption imported technology }\end{array}$ & $\begin{array}{l}100 \text { million } \\
\text { yuan }\end{array}$ & Positive & 0.0182 \\
\hline \multirow{6}{*}{$\begin{array}{l}\text { Energy and } \\
\text { environmental } \\
\text { protection ca- } \\
\text { pability } \\
(0.1436)\end{array}$} & $\begin{array}{l}\text { Wastewater discharge } \\
\text { per unit output }\end{array}$ & $\begin{array}{l}\text { Manufacturing wastewater dis- } \\
\text { charge / manufacturing output }\end{array}$ & $\begin{array}{c}10,000 \text { tons } \\
/ 100 \text { million } \\
\text { yuan }\end{array}$ & Negative & 0.0147 \\
\hline & $\begin{array}{l}\text { Exhaust emissions dis- } \\
\text { charge per unit output }\end{array}$ & $\begin{array}{l}\text { Manufacturing exhaust emis- } \\
\text { sions / manufacturing output }\end{array}$ & $\begin{array}{l}10,000 \text { tons } \\
/ 100 \text { million } \\
\text { yuan }\end{array}$ & Negative & 0.0147 \\
\hline & $\begin{array}{l}\text { Solid waste discharge } \\
\text { per unit output }\end{array}$ & $\begin{array}{l}\text { Manufacturing solid waste dis- } \\
\text { charge / manufacturing output }\end{array}$ & $\begin{array}{c}10,000 \text { tons } \\
/ 100 \text { million } \\
\text { yuan }\end{array}$ & Negative & 0.0147 \\
\hline & $\begin{array}{l}\text { Output value of three } \\
\text { waste comprehensive } \\
\text { utilization products }\end{array}$ & $\begin{array}{l}\text { Output value of all category C } \\
\text { manufacturing industry's three } \\
\text { waste comprehensive utilization } \\
\text { products }\end{array}$ & $\begin{array}{l}100 \text { million } \\
\text { yuan }\end{array}$ & Positive & 0.0482 \\
\hline & $\begin{array}{l}\text { Energy consumption } \\
\text { per unit output }\end{array}$ & $\begin{array}{l}\text { Manufacturing energy consump- } \\
\text { tion / manufacturing output }\end{array}$ & $\begin{array}{l}10,000 \text { tons } \\
\text { of standard } \\
\text { coal / } 100 \\
\text { million yuan }\end{array}$ & Negative & 0.0171 \\
\hline & $\begin{array}{l}\text { Coal consumption per } \\
\text { unit output }\end{array}$ & $\begin{array}{l}\text { Manufacturing Coal Consump- } \\
\text { tion /manufacturing output }\end{array}$ & $\begin{array}{l}10,000 \text { tons } \\
/ 100 \text { million } \\
\text { yuan }\end{array}$ & Negative & 0.0171 \\
\hline
\end{tabular}




\begin{tabular}{|c|c|c|c|c|c|}
\hline & $\begin{array}{l}\text { Electricity consump- } \\
\text { tion per unit output }\end{array}$ & $\begin{array}{l}\text { Manufacturing electricity con- } \\
\text { sumption / manufacturing output }\end{array}$ & $\begin{array}{c}100 \mathrm{million} \\
\mathrm{kWh} / 100 \\
\text { million yuan }\end{array}$ & Negative & 0.0171 \\
\hline \multirow{3}{*}{$\begin{array}{c}\text { Industrial } \\
\text { structure opti- } \\
\text { mization ca- } \\
\text { pability } \\
(0.2302)\end{array}$} & Huffman ratio & $\begin{array}{l}\text { Industrial output of consumer } \\
\text { goods / industrial output of capi- } \\
\text { tal goods }\end{array}$ & $\%$ & Positive & 0.0767 \\
\hline & $\begin{array}{l}\text { Proportion of high-tech } \\
\text { industry }\end{array}$ & $\begin{array}{l}\text { High-tech industry value added / } \\
\text { manufacturing value added }\end{array}$ & $\%$ & Positive & 0.0956 \\
\hline & $\begin{array}{l}\text { Market concentration } \\
\text { of top } 100 \text { industrial } \\
\text { enterprises }\end{array}$ & $\begin{array}{l}\text { Market share of top } 100 \text { enter- } \\
\text { prises / total market share }\end{array}$ & $\%$ & Positive & 0.0579 \\
\hline \multirow{4}{*}{$\begin{array}{l}\text { Social } \\
\text { service } \\
\text { capacity } \\
(0.1304)\end{array}$} & Number of employees & $\begin{array}{l}\text { Total employment in manufac- } \\
\text { turing }\end{array}$ & $\begin{array}{c}\text { Ten thou- } \\
\text { sand people }\end{array}$ & Positive & 0.0423 \\
\hline & $\begin{array}{l}\text { Proportion of employ- } \\
\text { ment }\end{array}$ & $\begin{array}{l}\text { Total employment in manufac- } \\
\text { turing/Total employment in } \\
\text { Yangtze River Delta Urban Ag- } \\
\text { glomeration }\end{array}$ & $\%$ & Positive & 0.0292 \\
\hline & Total profit and tax & $\begin{array}{l}\text { Total profits and taxes of manu- } \\
\text { facturing enterprises }\end{array}$ & $\begin{array}{c}100 \text { million } \\
\text { yuan }\end{array}$ & Positive & 0.0418 \\
\hline & $\begin{array}{l}\text { Per capita interest rate } \\
\text { of employees }\end{array}$ & $\begin{array}{l}\text { Total manufacturing profits and } \\
\text { taxes / Total employment in } \\
\text { manufacturing }\end{array}$ & $\begin{array}{l}\text { Ten thou- } \\
\text { sand } \\
\text { yuan/person }\end{array}$ & Positive & 0.0171 \\
\hline Dimension & Indicators & Description & Unit & Property & Weights \\
\hline
\end{tabular}

facturing green competitiveness. Technology introduction funds and technology digestion and absorption funds are used to reflect the ability to re-innovate. Compared with developed countries such as Japan and South Korea, Yangtze River Delta Urban Agglomeration have less funds for technology introduction and digestion and absorption, most imported technology is mostly at a low level and repeated introductions are common, which severely restricts the improvement of manufacturing re-innovation ability.

The dimension of energy environmental protection capabilities. Manufacturing has always been a large energy consumer and a major source of environmental pollution, energy environmental protection can reduce energy consumption, alleviate environmental pollution problems, and promote a dynamic equilibrium between efficient production and environmental governance. This dimension is mainly measured in terms of energy consumption, environmental pollution and the output value of three waste comprehensive utilization products. Among them, the wastewater discharge per unit output, exhaust emissions discharge per unit output and solid waste discharge per unit output reflect the total amount of three wastes discharged in manufacturing activities. The output value of three wastes comprehensive utilization products reflects the green development ability of manufacturing industry. Energy consumption per unit output, coal consumption per unit output, electricity consumption per unit output reflect the energy consumption of manufacturing enterprises in production activities, among them, energy consumption per unit output is used to measure the intensity of energy consumption, coal consumption per unit output is used to reflect the use of traditional high pollution energy, and power consumption per unit output is used to reflect the use of clean energy.
The dimension of industrial structure optimization capabilities. Promoting the optimization and upgrading of industrial structure is the key to promoting manufacturing industry sustainable development. At present, the structural problems faced by the manufacturing industry in Yangtze River Delta Urban Agglomeration are the core problems restricting its green competitiveness. Structural optimization is manifested in three aspects: rationalization of industrial structure, advanced industrial structure, and optimization of industrial organization structure. The Huffman ratio is a reflection of the rationalization of manufacturing industrial structure and the coordination of light industry and heavy industry; the proportion of high-tech industries reflects the advanced structure of the manufacturing industry and the proportion of resource-intensive industries and technology-intensive industries; the market concentration of the top 100 industrial enterprises is the embodiment of the optimization of manufacturing industry organizational structure, manufacturing industry can increase market concentration and strengthen its international market competitiveness through resource integration and alliance.

The dimension of social service capability. Social service capacity is mainly measured from employment and taxation. The number of employees is the index of total employment, and the proportion of employment to total employment is a relative index, they reflect the ability of manufacturing enterprises to absorb employment from different perspectives. It is the ultimate goal of Yangtze River Delta Urban Agglomeration economic development to actively provide the necessary jobs for social residents and increase their income, and the increase of residents' income will also promote labor force quality improvement, thus helping to enhance manufacturing industry green competitiveness. The total profit and 
tax rate and the per capita profit and tax rate of employees are tax indicators that reflect the contribution of manufacturing enterprises to the country. The more taxes the manufacturing industry pays, the more investment the government will make in public services, and ultimately the social environment within Yangtze River Delta Urban Agglomeration will be greatly improved.

\section{Construct grey relation projection compre- hensive evaluation model based on FAHP- maximum deviation combination weighting}

In order to give consideration to the advantages of subjective preference and objective information of review experts, and make the weighting reach the unity of subjective and objective, this paper uses the gray correlation projection comprehensive evaluation model based on the combination of FAHP-maximum deviation method to evaluate and analyze Yangtze River Delta Urban Agglomeration manufacturing green competitiveness index. This method can make the research results of manufacturing green competitiveness index evaluation more scientific and accurate, and avoid the possible deviation of single weighting method in determining the weights of evaluation indexes and indication gray characteristics.

\subsection{Combination weighting method based on FAHP-maximum deviation}

(1) Determination of subjective weight

Fuzzy Analytic Hierarchy Process (FAHP) is an extension of AHP in deal with uncertainty and ambiguity problems, its basic idea is to use a fuzzy matrix to replace expert's judgment matrix in AHP,it can effectively solve the significant difference between the consistency of comparative judgment matrix and that of human thinking. In this paper, FAHP method is used to calculate the subjective weight of each evaluation index, the calculation principle and process refer to the research of $\mathrm{Li}(2007)$.

(2) Determination of objective weights

The dispersion maximization method (MDM) is an objective weighting method based on the comparison of the dispersion of an indicator and the total dispersion of all indicators. Experts will weight indicators based on this ratio, a larger ratio indicates that the evaluation index is more important, and it will be given a greater weight, conversely, the less weight is given.

Drawing on the research of Wang (1998), suppose an evaluation system has $m$ evaluation objects and $n$ evaluation indicators, and the attribute value $x_{i j}$ $(i=1,2, \ldots, m ; j=1,2, \ldots, n)$ represents the data corresponding to the $j$ th index in the $i$ th evaluation object. The specific calculation steps are as follows: First of all, the data corresponding to the evaluation index should be dimensionless calculated to elimi- nate the gap between the dimension units of the index statistical data. The formula is as follows:

$$
\mathrm{Z}_{i j}=\frac{x_{i j}-\min _{1 \leq i \leq m}}{\max _{1 \leq i \leq m} x_{i j}-\min _{1 \leq i \leq m}}
$$

set up $w_{j}$ as the weight of indicator $j, w_{j} \geq 0$ and $\Sigma w_{j}=1, H_{i j}(w)$ represent the deviation between the evaluation object $i$ and other evaluation objects, then

$H_{i j}(w)=\sum_{i=1}^{m}\left|Z_{i j} w_{j}-Z_{l j} w_{j}\right|$

For index $j$, the total deviation between each evaluation object and other evaluation objects is:

$$
H_{j}(w)=\sum_{i=1}^{m} H_{i j}(w)=\sum_{i=1}^{m} \sum_{l=1}^{m} w_{j}\left|Z_{i j}-Z_{l j}\right|
$$

According to the idea of maximum deviation, the linear programming model of index weight is obtained as follows:

$$
\begin{aligned}
& \max H(w)=\sum_{j=1}^{n} \sum_{i=1}^{m} \sum_{l=1}^{m} w_{j}\left|Z_{i j}-Z_{l j}\right| \\
& \text { among : s.t. } \sum_{j=1}^{n} w_{j}=1, \quad w_{j}>0, \quad j=1,2, \cdots, \mathrm{n} .
\end{aligned}
$$

This model is solved according to the Lagrangian multiplier method and normalized to obtain the index deviation method weights as:

$$
w_{j}=\frac{\sum_{i=1}^{m} \sum_{l=1}^{m}\left|Z_{i j}-Z_{l j}\right|}{\sum_{j=1}^{n} \sum_{i=1}^{m} \sum_{l=1}^{m}\left|Z_{i j}-Z_{l j}\right|}
$$

Where: $\sum_{i=1}^{m} \sum_{l=1}^{m}\left|Z_{i j}-Z_{l j}\right|$ represents the deviation obtained by subtracting the absolute value from the normalized value of indicator $i$ of all $m$ evaluated objects and then summing it;

$\sum_{j=1}^{n} \sum_{i=1}^{m} \sum_{l=1}^{m}\left|Z_{i j}-Z_{l j}\right|$ represents the sum of the deviations of all $n$ indicators.

It can be seen from equation (5) that the deviation of evaluation index is directly proportional to its weight. The larger the deviation, the greater the weight of evaluation index; otherwise, the smaller the weight of evaluation index.

(3) Determination of combination weight

The method for determining the combination weights in this study is based on the literature Tao $\& \mathrm{Wu}$ (2001), the specific calculation process is as follows:

Set the subjective weight vector as

$W^{(1)}=\left(w_{1}^{(1)}, w_{2}^{(1)}, \cdots, w_{n}^{(1)}\right)^{T}$

The objective weight vector is $W^{(2)}=\left(w_{1}^{(2)}, w_{2}^{(2)}, \cdots, w_{n}^{(2)}\right)^{T}$

The combined weight vector is $W=\left(w_{1}, w_{2}, \cdots, w_{n}\right)^{T}$ 
Among them:

$w_{j}=\alpha w_{j}^{(1)}+(1-\alpha) w_{j}^{(2)}, \quad j=1,2, \cdots, \mathrm{n}$,

$\alpha$ is the preference coefficient, It reflects the analyst's preference for subjective and objective rights. This article set $\alpha=0.5$.

\subsection{Comprehensive evaluation model based on grey relation projection}

By introducing the principle of vector projection into the traditional gray correlation analysis, the gray correlation projection method corrects the fitting curve accuracy of the gray correlation analysis, avoids the single direction deviation of the gray correlation analysis, and comprehensively analyzes the relationship between indicators. The basic idea of this method is to compare the geometric relationship between the sequence and the reference sequence and the geometric shape of the curve. The closer the sequence curve and the geometric shape are, the greater the correlation degree is, indicating that the closer the decision-making scheme is to the ideal scheme, and vice versa. The main evaluation process of the gray correlation projection method is:

Step 1. Establish an evaluation matrix.

Suppose there are $m$ evaluation objects and $n$ evaluation indexes in an evaluation system, $y_{i j}$ represents the value of object $U_{i}$ to the index $V_{j}(i=1,2, \ldots, m$; $j=1,2, \ldots, n)$, from which the optimal index value $y_{0 j}$ of evaluation object $U_{0}$ can be found.

When indicator $V_{j}$ is a positive indicator, $y_{0 j}=\max \left(y_{1 j}, y_{2 j}, \cdots, y_{m j}\right)$

When indicator $V_{j}$ is a reverse indicator, $y_{0 j}=\min \left(y_{1 j}, y_{2 j}, \cdots, y_{m j}\right)$

Then the evaluation matrix can be established, $Y=\left(\mathrm{Y}_{i j}\right)_{(\mathrm{m}+1) \times \mathrm{n}}, \quad i=0,1,2, \cdots, m ; j=1,2, \cdots, \mathrm{n}$

Step 2. Initialization.

According to the standardized evaluation matrix $Y=\left(y_{i j}\right)_{(\mathrm{m}+1) \times \mathrm{n}}$,

the initial evaluation matrix

$Y^{\prime}=\left(y_{i j}^{\prime}\right)_{(\mathrm{m}+1) \times \mathrm{n}}$

is established, where

When indicator $V_{j}$ is a positive indicator,

$y_{i j}^{\prime}=\frac{y_{i j}}{y_{0 j}}$

When indicator $V_{j}$ is a reverse indicator,

$y_{i j}^{\prime}=\frac{y_{0 j}}{y_{i j}}$

Step 3. Establish a gray correlation judgment matrix between the evaluation plan and the ideal plan.

Ideal scheme $y^{\prime}{ }_{0 j}$ is used as the reference factors, and the evaluation scheme $y^{\prime}{ }_{i j}$ is used as subfactor. The correlation degree $r_{i j}$ of $y^{\prime}{ }_{i j}$ with respect to $y^{\prime}{ }_{0 j}$ is calculated, and a gray correlation degree judgment ma$\operatorname{trix} R=\left(\mathrm{r}_{i j}\right)_{(\mathrm{m}=1) \times \mathrm{n} \times \mathrm{n}}$ is constructed, where

$$
r_{i j}=\frac{\min _{m} \min _{n}\left|y_{0 j}^{\prime}-y_{i j}^{\prime}\right|+\delta \max _{m} \max _{n}\left|y_{0 j}^{\prime}-y_{i j}^{\prime}\right|}{\left|y_{0 j}^{\prime}-y_{i j}^{\prime}\right|+\delta \max _{m} \max _{n}\left|y_{0 j}^{\prime}-y_{i j}^{\prime}\right|}
$$

$\delta \in(0,1)$ is the resolution coefficient, which is used to adjust the size of the comparison environment, usually take $\delta=0.5$.

Step 4. comprehensive evaluation.

According to the above combined weight vector $W=\left(w_{1}, w_{2}, \ldots, w_{n}\right)^{T}$, the gray correlation projection weight is calculated as $\bar{W}=\left(\overline{w_{1}}, \overline{w_{2}}, \cdots, \overline{w_{n}}\right)$, among them,

$$
\overline{w_{j}}=\frac{w_{j}^{2}}{\sqrt{\sum_{j=1}^{n} w_{j}^{2}}}
$$

Based on the size of gray correlation projection value, the comprehensive evaluation of each evaluation object is carried out. The gray correlation projection value of object $i$ is:

$Z_{i}=\sum_{j=1}^{n} r_{i j} \overline{w_{j}}, \quad i=1,2, \cdots, m$

\section{Yangtze River Delta Urban Agglomeration manufacturing green competitiveness index evaluation}

Based on the grey correlation projection comprehensive evaluation model of FAHP- maximum deviation combined weighting, this research compares and analyzes Yangtze River Delta Urban Agglomeration manufacturing green competitiveness index from 2014 to 2018. According to the State Council's Guiding Opinions on Promoting the Development of the Yangtze River Economic Belt by the Golden Waterway, there are 26 cities in the central area of Yangtze River Delta Urban Agglomeration, including: Shanghai, Nanjing, Wuxi, Changzhou, Suzhou, Nantong, Yangzhou, Zhenjiang, Yancheng, Taizhou, Hangzhou, Ningbo, Huzhou, Jiaxing, Shaoxing, Jinhua, Zhoushan, Taizhou, Hefei, Wuhu, Ma'anshan,Tongling, Anqing, Chuzhou, Chizhou, Xuancheng (covering an area of 225000 square kilometers), through these urban radiation to drive the high-quality development of Yangtze River Delta. The research data comes from China Statistical Yearbook (2014-2018), National Economic and Social Development Bulletin (2014-2018), Jiangsu, Zhejiang, Anhui and Shanghai Statistical Yearbook (2014-2018), and China's Manufacturing Development Research Report (2014-2018). The statistical caliber of indicators of economic creative ability, resource environmental protection ability, industrial structure optimization ability and social security ability is the entire manufacturing industry in Yangtze River Delta Urban Agglomeration, and the statistical caliber of scientific and technological innovation ability indicators is large and medium-sized 
manufacturing enterprises in Yangtze River Delta Urban Agglomeration.

\subsection{Index weight calculation and analysis}

According to the calculation steps of index weighting coefficients based on the FAHP-dispersion maximization combination weighting method proposed above, Matlab was used to measure the time-series three-dimensional data of the 29 indicators and 5 dimensions in the evaluation index system, the resulting comprehensive weights are shown in Table 1.

Economic creativity weight coefficient ranks first in all dimension, being 0.2526 , which shows that economic creative capacity bears the responsibility of providing the most basic material and economic basis for Yangtze River Delta Urban Agglomeration manufacturing green competitiveness index improvement, and is the basic guarantee for improving manufacturing green competitiveness to achieve the goal of rapid development. On April 5, 2014, the State Council proposed to take Shanghai as the leader and vigorously develop the economic belts of Jiangsu, Zhejiang and Anhui. On May 11, 2016, the executive meeting of the State Council passed the Yangtze River Delta Urban Agglomeration Development Plan and proposed to foster higher levels of economic growth. On November 18, 2018, the opinions of the CPC Central Committee and the State Council on establishing a more effective new mechanism for regional coordinated development clearly required Shanghai to lead the development of Yangtze River Delta Urban Agglomeration. With the strong support of government departments, Yangtze River Delta Urban Agglomeration has become the economic center with the fastest economic development speed, the largest economic aggregate scale, the most development potential and the strongest comprehensive strength in China. From the early days of its establishment to now, the international capital and private capital accumulated rapidly in Yangtze River Delta Urban Agglomeration are not only growing in scale, but also promoting the rapid economic development of the region with its unique vitality. Driven by the improvement of economic creativity, the total output value of manufacturing industry, product sales rate and enterprise unit output value of Yangtze River Delta Urban Agglomeration all show a strong correlation with green competitiveness. At the same time, they also promote the common development of the other four dimensions and form a strong economic coordination effect within the urban agglomeration.

The weight coefficients of scientific and technological innovation ability (0.2432) and industrial structure optimization ability $(0.2302)$ ranked second and third respectively. Among them, the weight coefficients of R\&D personnel proportion and R\&D expenditure are higher, 0.0365 and 0.0348 respec- tively. The Yangtze River Delta Urban Agglomeration development plan clearly points out that Yangtze River Delta Urban Agglomeration should be built into a highland of scientific and technological innovation with global influence. At present, R\&D institutions and universities in the region are relatively dense, Universities include Fudan University, Nanjing University, Zhejiang University, China University of science and technology, Shanghai Jiaotong University; about R\&D institution, Shanghai alone has 18 world-class R\&D and transformation functional platforms, 8 international laboratories and 10 national engineering technology research centers. Secondly, the number and quality of science and technology enterprises in the zone are leading in the country. Taking 2017 as an example, the number of high-tech enterprises in 9 cities exceeded 1,000: 7,668 in Shanghai, 4,469 in Suzhou, 2844 in Hangzhou, 1850 in Nanjing, 1669 in Wuxi, 1666 in Hefei, 1479 in Ningbo, 1,234 in Changzhou, and 1045 in Nantong. Among them, iFLYTEK, East China Pharmaceutical, SAIC Group, 360 and other leading innovative companies have played an important leading role. Third, research investment and synergistic polarization effect are significant. According to the report of 2019 Yangtze River Delta integrated regional collaborative innovation index released by Shanghai Institute of science, the R\&D investment in Yangtze River Delta Urban Agglomeration increased significantly from 2010 to 2017, and the growth rate of $\mathrm{R} \& \mathrm{D}$ investment was generally higher than that of GDP, in 2017 ,the overall R\&D investment intensity was $2.71 \%$. However, it is worth noting that there are significant regional differences in $R \& D$ investment, among them, the intensity of $R \& D$ investment in Shanghai is $3.93 \%$, and Jiangsu, Zhejiang, and Anhui are 2.63\%, 2.45\% and $2.05 \%$ respectively. The number of domestic patent applications for cross provincial cooperation increased from 357 in 2010 to 1671 in 2017, a nearly five-fold increase in 7 years. The high-level operation of talent flow in the region has formed four scientific research cooperation trunk lines: Shanghai-Nanjing cooperation trunk line, Shanghai-Hangzhou cooperation trunk line, Shanghai-Hefei cooperation trunk line and Nanjing-Hangzhou cooperation trunk line. The promotion of technological innovation ability provides an important guarantee for the innovation and development of manufacturing industry.

The weight coefficients of energy and environmental protection capacity $(0.1436)$ and social service capacity (0.1304) are relatively small. At present, although Yangtze River Delta Urban Agglomeration is developing towards the integration of strategic emerging industries and advanced manufacturing industries, the quality of its industrial ecological environment, including the quality of natural environment and social environment, still lags far behind the world-class standard, and has little contribution to 


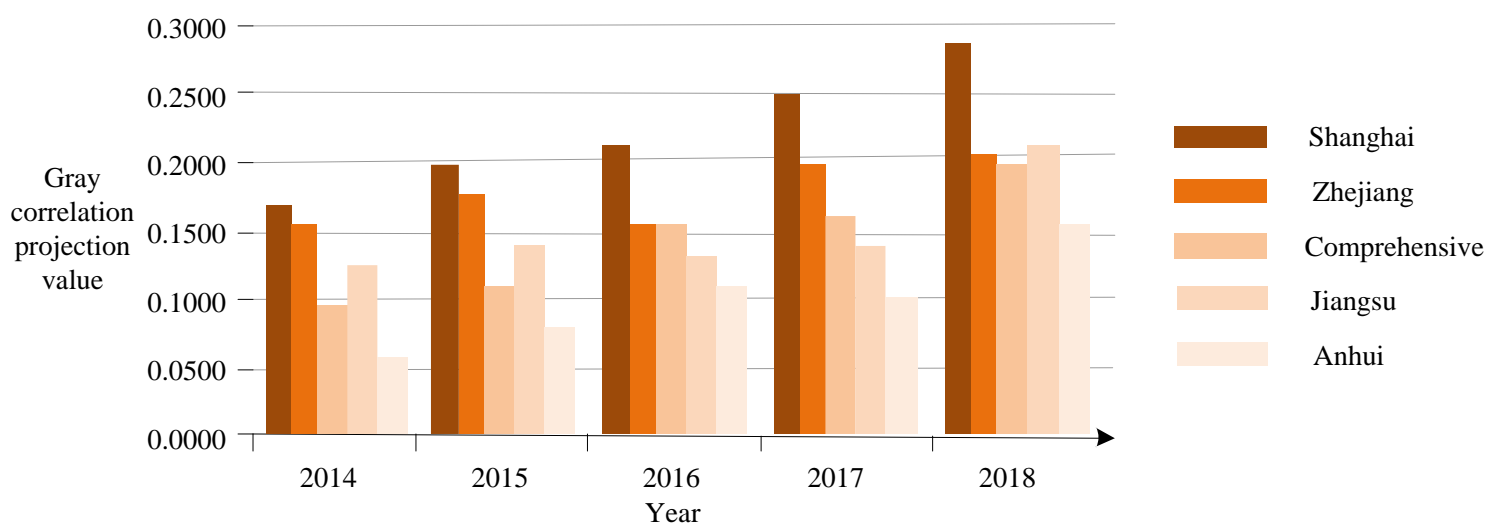

Figure 1. Change trend of Yangtze River Delta Urban Agglomeration manufacturing green competitiveness index - Horizontal

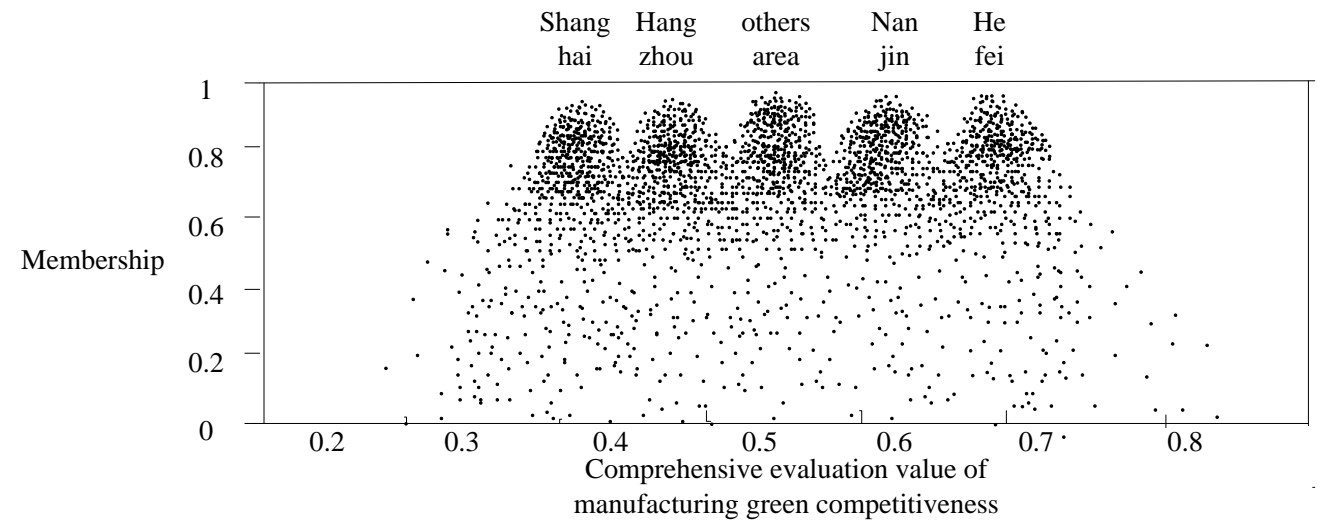

Figure 2. Normal Cloud Membership Distribution of Yangtze River Delta Urban Agglomeration manufacturing green competitiveness index

the overall green competitiveness. Since the establishment of the cooperation mechanism, Yangtze River Delta Urban Agglomeration have made a lot of positive explorations in the aspects of joint prevention and control of air pollution, comprehensive prevention and control of water pollution, emergency disposal of cross-border pollution, regional hazardous waste environmental management, etc., but concerted efforts of multiple parties are still needed. Such as the three wastes governance, the current governance effect is low, energy consumptive huge and renewable energy and clean low-carbon energy supply is limited, in the future, it is necessary to optimize the inter-regional coordination policy, unify the planning, standards and implementation, and establish a regional ecological environment governance system of social co governance. In terms of social service capacity, GDP of Yangtze River Delta Urban Agglomeration in 2018 is 17.86 trillion yuan, of which the total profits and taxes in Shanghai are 100.31 billion yuan, while those in Nanjing, Hangzhou and Hefei are 18.341 billion yuan, 27.498 billion yuan and 19.841 billion yuan respectively. Compared with the world-class economic circle, the taxation level of cities still needs to be improved. At the same time, due to the 150 million resident population of urban agglomerations, the per capita disposable income of urban residents is not high, for example, the per capita income of Zhoushan, Wuxi, Changzhou, and Yangzhou is in the range of RMB 13,000-19,000. Regarding employment, data in 2018 shows that Shanghai alone has absorbed $22 \%$ of university graduates from the Yangtze River Delta Urban Agglomeration. While taking the Yangtze River Delta Urban Agglomeration as a whole, the average retention rate of fresh students has reached $90.3 \%$, which shows that the Yangtze River Delta Urban Agglomeration has initially formed a relatively benign talent retention atmosphere and flow mechanism.

\subsection{Yangtze River Delta Urban Agglomeration manufacturing green competitiveness index comparative analysis}

In order to clearly analyze the spatio-temporal evolution characteristics of Yangtze River Delta Urban Agglomeration manufacturing green competitiveness, on the basis of standardizing the evaluation index data, calculate and evaluate the green competitiveness growth index of the manufacturing industry in the Yangtze River Delta urban agglomeration from 2014 to 2018 by using the gray correlation projection comprehensive evaluation model based on FAHP-maximum deviation combined weighting es- 
Table 2. Growth of Yangtze River Delta Urban Agglomeration manufacturing green competitiveness index

\begin{tabular}{|c|c|c|c|c|c|c|c|c|c|c|c|c|}
\hline \multirow[t]{2}{*}{ Area } & \multicolumn{2}{|c|}{$\begin{array}{l}\text { Economic cre- } \\
\text { ativity }\end{array}$} & \multicolumn{2}{|c|}{$\begin{array}{c}\text { Scientific and } \\
\text { technological } \\
\text { innovation ca- } \\
\text { pabilities }\end{array}$} & \multicolumn{2}{|c|}{$\begin{array}{l}\text { Energy envi- } \\
\text { ronmental } \\
\text { protection ca- } \\
\text { pability }\end{array}$} & \multicolumn{2}{|c|}{$\begin{array}{l}\text { Industrial } \\
\text { structure opti- } \\
\text { mization ca- } \\
\text { pability }\end{array}$} & \multicolumn{2}{|c|}{$\begin{array}{c}\text { Social service } \\
\text { capacity }\end{array}$} & \multicolumn{2}{|c|}{$\begin{array}{l}\text { Comprehen- } \\
\text { sive evalua- } \\
\text { tion value }\end{array}$} \\
\hline & 2014 & 2019 & 2014 & 2019 & 2014 & 2019 & 2014 & 2019 & 2014 & 2019 & 2014 & 2019 \\
\hline Shanghai & 0.151 & 0.345 & 0.109 & 0.394 & 0.103 & 0.287 & 0.099 & 0.218 & 0.118 & 0.286 & 0.116 & 0.293 \\
\hline Nanjing & 0.052 & 0.114 & 0.034 & 0.109 & 0.028 & 0.094 & 0.027 & 0.096 & 0.021 & 0.095 & 0.026 & 0.101 \\
\hline Wuxi & 0.031 & 0.065 & 0.015 & 0.058 & 0.013 & 0.046 & 0.018 & 0.057 & 0.012 & 0.034 & 0.018 & \\
\hline Changzhou & 0.014 & 0.051 & 0.008 & 0.037 & 0.009 & 0.025 & 0.007 & 0.031 & 0.009 & 0.022 & 0.017 & 0.028 \\
\hline Suzhou & 0.056 & 0.102 & 0.049 & 0.099 & 0.031 & 0.068 & 0.035 & 0.091 & 0.022 & 0.059 & 0.037 & .088 \\
\hline Nantong & 0.009 & 0.033 & 0.007 & 0.028 & 0.005 & 0.026 & 0.009 & 0.021 & 0.006 & 0.017 & 0.007 & 0.022 \\
\hline Yangzhou & 0.008 & 0.027 & 0.009 & 0.015 & 0.005 & 0.028 & 0.008 & 0.011 & 0.005 & 0.024 & 0.006 & 0.020 \\
\hline Zhenjiang & 0.009 & 0.031 & 0.007 & 0.022 & 0.006 & 0.024 & 0.007 & 0.018 & 0.003 & 0.012 & 0.005 & 0.019 \\
\hline Yancheng & 0.011 & 0.042 & 0.011 & 0.028 & 0.007 & 0.027 & 0.007 & 0.029 & 0.004 & 0.010 & 0.006 & 0.025 \\
\hline Taizhou & 0.013 & 0.026 & 0.009 & 0.017 & 0.005 & 0.019 & 0.006 & 0.015 & 0.002 & 0.009 & 0.006 & 0.012 \\
\hline Hangzhou & 0.103 & 0.136 & 0.047 & 0.101 & 0.059 & 0.104 & 0.059 & 0.104 & 0.057 & 0.114 & 0.062 & 0.112 \\
\hline Ningbo & 0.046 & 0.088 & 0.049 & 0.067 & 0.035 & 0.058 & 0.038 & 0.058 & 0.027 & 0.061 & 0.036 & 0.063 \\
\hline Huzhou & 0.016 & 0.053 & 0.011 & 0.034 & 0.008 & 0.029 & 0.008 & 0.026 & 0.007 & 0.018 & 0.009 & 0.027 \\
\hline Jiaxing & 0.021 & 0.047 & 0.013 & 0.023 & 0.008 & 0.022 & 0.010 & 0.021 & 0.008 & 0.019 & 0.011 & 0.024 \\
\hline Shaoxing & 0.015 & 0.028 & 0.009 & 0.018 & 0.007 & 0.016 & 0.006 & 0.014 & 0.006 & 0.017 & 0.008 & 0.019 \\
\hline Jinhua & 0.005 & 0.052 & 0.004 & 0.026 & 0.005 & 0.021 & 0.004 & 0.017 & 0.004 & 0.016 & 0.004 & 0.022 \\
\hline Zhoushan & 0.009 & 0.061 & 0.008 & 0.042 & 0.006 & 0.037 & 0.007 & 0.039 & 0.004 & 0.019 & 0.008 & 0.033 \\
\hline Taizhou & 0.010 & 0.042 & 0.007 & 0.033 & 0.004 & 0.028 & 0.006 & 0.025 & 0.003 & 0.016 & 0.005 & 0.029 \\
\hline Hefei & 0.067 & 0.119 & 0.055 & 0.098 & 0.049 & 0.086 & 0.042 & 0.103 & 0.032 & 0.077 & 0.049 & 0.091 \\
\hline Wuhu & 0.017 & 0.057 & 0.013 & 0.046 & 0.007 & 0.033 & 0.008 & 0.034 & 0.009 & 0.034 & 0.012 & 0.038 \\
\hline Maanshan & 0.013 & 0.045 & 0.011 & 0.037 & 0.006 & 0.028 & 0.005 & 0.023 & 0.007 & 0.023 & 0.009 & 0.030 \\
\hline Tongling & 0.007 & 0.031 & 0.005 & 0.028 & 0.004 & 0.026 & 0.002 & 0.008 & 0.003 & 0.022 & 0.004 & 0.021 \\
\hline Anqing & 0.008 & 0.037 & 0.006 & 0.029 & 0.004 & 0.021 & 0.005 & 0.017 & 0.004 & 0.020 & 0.005 & 0.025 \\
\hline Chuzhou & 0.004 & 0.030 & 0.003 & 0.017 & 0.003 & 0.009 & 0.002 & 0.009 & 0.002 & 0.009 & 0.003 & 0.012 \\
\hline Chizhou & 0.005 & 0.033 & 0.002 & 0.017 & 0.010 & 0.026 & 0.002 & 0.010 & 0.012 & 0.023 & 0.007 & 0.024 \\
\hline Xuancheng & 0.007 & 0.037 & 0.006 & 0.022 & 0.002 & 0.011 & 0.008 & 0.016 & 0.001 & 0.009 & 0.003 & 0.018 \\
\hline
\end{tabular}

tablished above. The results are shown in Figure 1, Figure 2, Table 1 and Table 2.

According to the comprehensive evaluation results, it can be found that:

(1) Although the gray correlation projection value of Yangtze River Delta Urban Agglomeration manufacturing green competitiveness index in 2014-2018 reflects a certain degree of volatility, it generally shows a relatively stable and sustainable improvement trend. From the evaluation result, the growth rate was slow in the early stage, and then accelerated significantly. Therefore, the change of manufacturing green competitiveness index in the sample area can be divided into two stages: initial fluctuation period and rapid growth period, which is closely related to the development environment of manufacturing industry in Yangtze River Delta. Yangtze River Delta Urban Agglomeration has experienced many times of expansion. In 2014, it was expanded to 26 cities, forming the current main framework of three provinces and one city: Shanghai, Jiangsu, Zhejiang and Anhui. In October 2019, it was expanded to 41 cities under this framework. In the initial stage of the formation of the main framework, because the integrated market system has not been established and the factor market is in a segmentation state, it is difficult for the factor resources to flow across regions, and economic growth efficiency was greatly suppressed.In May 2016, the Yangtze River Delta Urban Agglomeration Development Plan proposed to build a network spatial pattern of one core, five circles and four belts. At the same time, with the development of communication technology, transportation costs and coordination costs caused by the separation of enterprise departments have declined significantly, and the Yangtze River Delta has changed from product division to urban functional division. In 2017, the GDP, number of three domestic patent applications and the actual use of foreign capital of Yangtze River Delta Urban Agglomeration accounted for $24 \%, 34 \%$, and $58 \%$ of the country respectively, and became the key to the steady development of China's economy and innovation.In 2018, the Yangtze River Delta Regional Cooperation Office issued the first three-year action plan for the integrated development of Yangtze River Delta Urban Agglomeration, which puts forward specific requirements for optimizing the layout of key industries, establishing an integrated market system and a new mechanism for regional coordinated development. At the end of 2018, in the face of complex and severe external environment and downward pressure on the economy, Yangtze River Delta Urban Agglomeration has made good development: the GDP of 26 cities reached 17.86 trillion RMB, an increase of 1.34 trillion yuan over the previous year; 
the total retail sales of social consumer goods reached 7.15 trillion yuan, an increase of 758.7 billion yuan over the previous year; general public budget revenue reached 2.16 trillion yuan, an increase of 189.8 billion yuan over the previous year; the per capita disposable income of urban residents was 48382 yuan, an average increase of 3395 yuan over the previous year; the average per capita disposable income of rural residents was 24583 yuan, an average increase of 1887 yuan over the previous year; in terms of foreign trade, the average growth rate of total exports in US dollars increased by $10.3 \%, 0.4$ percentage points higher than the national average.

(2) Manufacturing green competitiveness in Yangtze River Delta Urban Agglomeration varies greatly from city to city, but regional dynamics are becoming increasingly coordinated and balanced, and local development in each city is more personalized. Specifically, the leading city, Shanghai, with a green competitiveness index growth of 0.177 , ranking first in terms of competitiveness growth scores in economic development, scientific and technological innovation, social services and other fields, especially in terms of scientific and technological innovation capacity, which is developing rapidly. The hub cities include Nanjing, Suzhou, Hangzhou, Ningbo, Wuxi and Hefei, which are comprehensive hubs that have a radiating role in Yangtze River Delta Urban Agglomeration, their green competitiveness index increases significantly, with the growth rate of 0.075 , $0.051,0.050,0.027,0.031$ and 0.042 respectively. Among them, Nanjing is in a leading position in the number of cooperative patents, famous universities, and the passenger traffic volume of aircraft and railway; Suzhou leads the way in terms of the number of co-patent patents, fiscal technology expenditures, and the number of manufacturing 500 headquarters; Hangzhou leads the way in the number of rail passenger transport and the number of famous universities; Ningbo is in the leading position in road, railway, aviation and shipping; Hefei, with outstanding performance in the field of scientific and technological innovation, is a comprehensive national science center with international influence. There are $9 \mathrm{im}-$ portant node cities, including: Zhenjiang, Nantong, Jinhua, Taizhou, Changzhou, Zhoushan, Yangzhou, Xuancheng and Yancheng. Their green competitiveness index increases are $0.014,0.015,0.018,0.024$, $0.011,0.025,0.014,0.015$ and 0.019 respectively. These cities are relatively inferior in comprehensive capacity, but have outstanding performance in individual sub thematic areas, for example, Xuancheng, it has outstanding performance in energy saving and emission reduction. General node cities include Jiaxing, Wuhu, Shaoxing, Chuzhou, Huzhou and Taizhou, their green competitiveness index increases by $0.013,0.026,0.011,0.009,0.018$ and 0.006 respectively, the overall collaborative capacity of these cit- ies is not outstanding, most of them are local economic centers, and there is a large space to improve their future collaborative development capacity.There are 4 local cities: Chizhou, Anqing, Tongling, and Ma'anshan, their green competitiveness indexes have increased by $0.017,0.020,0.017$, and 0.021 respectively, these cities have weak collaborative development capabilities, and have a significant gap compared with the former four types cities. In the follow-up, according to the development idea of $R \& D$ in Shanghai, production outside; mind in Shanghai, body outside; key manufacturing in Shanghai, general industry chain around, the industrial gradient division of labor pattern will continue to deepen. Shanghai will further play a leading role and take the free trade pilot zone and reform in key areas as the starting point to improve its strategic positioning and promote the overall acceleration of integrated development. Jiangsu will focus on the needs of industrial upgrading, organize and carry out key core technology research, implement the transformation of major scientific and technological achievements, and promote the development of new industries, new industries and new modes. For example: Nanjing, there will be a net increase of 1,282 high-tech companies in 2018, an increase of nearly $70 \%$, and it will continue to be strengthened in the future; Nantong will use such carriers as the development zone and Shanghai Stock connect cooperation park to undertake the industrial transfer in Shanghai and expand its industrial chain. About Zhejiang, the added value of the digital economy core industries in 2018 is 554.8 billion yuan, an increase of $13.1 \%$ over the previous year. In the future, they will focus on digital technology, promote the integration of industries, and accelerate the rapid development of new industries such as urban rail vehicles, new energy vehicles, industrial robots, etc. For example, Ningbo will focus on free trade port, intelligent manufacturing, biomedicine and other highend manufacturing industries, and realize dislocation development with Shanghai in different links of industrial chain by using comparative advantages; Jiaxing will fully integrate with Shanghai demonstration zone and strive to build a place where Zhejiang and Shanghai take the lead in integrating innovation policies and where high-end industries develop in coordination. Anhui will speed up the pace of integration, comprehensively deepen the division of labor and cooperation with Shanghai, Jiangsu and Zhejiang, and promote information sharing, as the capital of Anhui Province and an important node city, Hefei has now built the largest China home appliance industry base in China, and will deepen the development mode of leading enterprises-large projects-industrial chain-manufacturing base-Industrial Cluster in the future.

(3) Industrial structure optimization is the key to enhance manufacturing green competitiveness index. 
Yangtze River Delta Urban Agglomeration industrial structure has been upgraded, in 2018, the three industrial structure adjustments were 3.0:42.7:54.3, the proportion of the tertiary industry increased from $49.6 \%$ to $53.3 \%$, and the added value accounted for $20.7 \%$ of the whole country, which was 1 percentage point higher than the proportion of GDP in the same period. In terms of proportion, 9 out of 26 cities account for more than 50\%, and Shanghai, Nanjing and Hangzhou account for more than $60 \%$. The strong innovation investment in Yangtze River Delta Urban Agglomeration manufacturing industry has led to the emergence of a large number of advanced manufacturing industries, such as high-end equipment manufacturing in Nanjing, electronic industry in Suzhou and modern display industry in Hefei. The optimization of industrial structure has significantly improved the quality and efficiency of economic growth. In addition to increasing financial revenue, the enterprises's production and marketing capabilities have significantly improved. In 2018, the average industrial production and marketing rate was $98.3 \%, 0.8$ percentage points higher than the previous year. However, judging from the lagging factors restricting the manufacturing green competitiveness, energy and environmental protection capabilities still needs to be strengthened, and the space for social security capacity to be improved is huge. Although energy conservation and emission reduction have certain effect, in 2018, the industrial power consumption of the Yangtze River Delta Urban Agglomeration was 766.3 billion $\mathrm{kwh}$, an increase of $4.7 \%$ year-on-year, $2.3 \%$ lower than that in 2017, but the emissions and emission intensity of smoke and dust, manufacturing wastewater and their emission intensity are relatively high. In terms of social security, the income of urban and rural residents has steadily increased, and market prices have risen by $2.0 \%$, a slight increase of 0.3 percentage points from the previous year, which has remained basically stable. However, in some regions, such as Yancheng, Taizhou, and Anqing, the proportion of manufacturing employees in the total number of employees is not high, and the per capita profit and tax rate is also a short board indicator, which indicates that the role of radiating social benefits needs to be strengthened. It also indicates that the overall development level of manufacturing industry is insufficient, the labor-intensive industries are relatively concentrated, the transformation and upgrading of traditional manufacturing industry to high value-added industry needs to be accelerated.

\section{Conclusions and policy recommendations}

With the aggravation of international economic competition, as an important engine of economic and social development, Yangtze River Delta urban agglomeration has been highly concerned by national leaders and government departments. Based on combing existing manufacturing green competitiveness issues of Yangtze River Delta Urban Agglomeration, following the integrated development theory of integrating into national strategy, promoting economic transformation, deepening key topics, improving development mechanism and enhancing people's livelihood and the connotation of new industrialization road development,this paper builds a Yangtze River Delta Urban Agglomeration manufacturing industry green competitiveness index evaluation index system covering the five dimensions of economic creativity, technological innovation, industrial structure optimization, energy environmental protection, and social service capabilities, and innovatively uses the comprehensive evaluation model of gray correlation projection method based on FAHP-maximum deviation combination weighting evaluated the Yangtze River Delta Urban Agglomeration manufacturing green competitiveness index. The results show that the differences of area manufacturing green competitiveness index are mainly reflected in the ability of economic creativity; manufacturing green competitiveness in different regions is quite different, and the momentum is gradually becoming balanced; industrial structure in the region has been upgraded, but there is huge room for manufacturing green competitiveness improvement in node cities and local cities.

Based on the above conclusions, this article puts forward the following policy recommendations:

(1) Economic growth is the key point to promote the sustainable improvement of Yangtze River Delta Urban Agglomeration manufacturing green competitiveness, only with economic benefits can there be a motive force for sustainable development, and can provide material support for develop technology, improve efficiency, increase employment and protect environment.First, manufacturing economy's income-generating output value and product market benefits covered by the green competitiveness index all show a strong correlation with Yangtze River Delta Urban Agglomeration manufacturing green competitiveness.In the later stage, we should focus on the agglomeration area to create a batch of highquality growth poles of manufacturing development. Around the fields of electronic information, biomedicine, aerospace, high-end equipment, new materials, energy conservation and environmental protection, automobile, green chemical industry, textile and clothing, intelligent home appliances, etc., a number of national strategic emerging industrial bases will be built to promote the modernization and advancement of the industrial chain and seize the commanding height of industrial development. Secondly, R\&D and transformation platform plays an increasingly important role in gathering resources, building a technology innovation achievement transformation platform, and focusing on solving the problem that the insufficient transformation benefits 
have weak support for manufacturing green competitiveness index. Only from the perspective of Shanghai planning, $30 \mathrm{R} \& \mathrm{D}$ and transformation functional platforms will be built by 2020 . At present, 18 platforms have been built, involving multiple manufacturing fields. In 2018, Shanghai exported more than 3300 items technologies to Jiangsu, Zhejiang and Anhui through the platform, with a transaction amount of 17.3 billion yuan. Suzhou, Ningbo, Hefei and other places also have state-level transformation platforms with sufficient space and venues, which provide great convenience for the landing and transformation of scientific and technological achievements.In the future, we should focus on the construction and operation of platforms in hub cities and key node cities, should focus on major national strategic needs, gather technology SMEs, integrate research and development, production, financing, incubation and international cooperation, to make up the gap between basic research and industrialization of scientific and technological achievements. Third, focusing on the effective guidance of improving the positive incentive effect of technological innovation on the level of manufacturing green competitiveness, it is necessary to promote the policy adjustment, and further promote the manufacturing platform system and regulations in the region with the full role of market mechanism, and steadily promote innovation based on the long-term and practical conditions.

(2) Regional spatial re-planning, cities of different levels interact with each other through complementary functions and coordinated development to strengthen the integration of industrial spatial resources and reduce homogeneous competition. Collaborative development should be based on strategy, innovation and optimization. First of all, plan from the overall situation, break the rigid boundaries of administrative divisions, and clarify the functions and development directions of different cities and functional plates based on the respective advantages and characteristics of 26 cities: Shanghai's science and technology innovation center and free trade experimental area, Jiangsu's coastal development and southern Jiangsu modernization demonstration area, Zhejiang's marine economic development demonstration area and Zhoushan Islands new area, Anhui's Wanjiang City belt connect to the industrial transfer demonstration area, give full play to the advantages of various policies, and promote inter regional talent flow, resource allocation and industrial division of labor. Second, create a regional manufacturing innovation value chain system with high value-added production activities, deepen the docking and cooperation of intelligent networked cars, industrial Internet, $5 \mathrm{G}$ and other industrial chains with new technologies, new models and new mechanisms, and build Shanghai's biomedicine manufacturing industry, Ningbo's electronics and information manufacturing industry, Suzhou's high-end equipment manufacturing industry, Hefei's integrated circuit manufactur- ing industry, and other world-class manufacturing industry clusters, accelerate the research of core technologies and solve the hidden dangers of key links being restricted by others. Third, focus on optimizing and adjusting the industrial structure of manufacturing industry in important and general node cities. The important node cities themselves have relatively strong manufacturing development heritage, focusing on cultivating a group of outstanding manufacturing enterprises with world-class companies. The basic development of manufacturing in general node cities is relatively weak, and new materials and new energy can be cultivated based on the existing industrial structure system to form a unique manufacturing green competitive brand effect.

(3) Strengthen the ecological co-construction of regional manufacturing industry, cooperating in the whole process of policy design, implementation, and evaluation around the aspects of total amount control and industry standards, improve the social service security level of manufacturing industry, establish the public facilities and service system across administrative regions, and provide guarantee for promoting the overall development of urban agglomeration. First of all, the air and water pollution of Yangtze River Delta Urban Agglomeration has the characteristics of regional linkage, and the construction of the world-class urban agglomeration is inseparable from the delicate, environmentally friendly and livable regional environment. The coordinated development in the local cities (like: Chizhou, Anqing, Tongling and Ma'anshan) is weak, and the green manufacturing capacity needs to be improved. Various types of pollutants must be controlled from the source, mainly the pollution sources with large emissions such as thermal power plants and industrial boilers, the in-depth cooperation of productive services can be regarded as the development focus of local cities' manufacturing industry in the next period, promote the cross-border integration of labor resource advantage elements of local cities and financial, capital, technology and other elements of leading cities and hub cities, and improve the radiation driving role of green competitive advantages of leading cities and hub cities. Secondly, learn from the relatively mature models and experiences of large international urban agglomerations, such as UK integration coordination mode of the administrative structure of the Greater London urban agglomeration, U.S. Urban Coordination and Ad Hoc Institutional Models, Japan 's core city-dominated inter-city coordination model, to build and improve the coordination mechanism of Yangtze River Delta Urban Agglomeration,emphasize demand-oriented and guide the participation of social forces to improve the level of socialization and professionalization of manufacturing services. Third, focus on the flow and sharing of innovative talents, vigorously expand the operating mode of capital, talent, technology and other advantageous resources in Shanghai, Hangzhou, Nanjing and Su- 
zhou, and improve the level of social service security in manufacturing industry.

\section{Funding}

This research was funded by The National Natural Science Foundation of China (No. 71871134), Planning of Shanghai Soft Science (No.17692103800; No.18692104400).

\section{References}

1. BILL S., PAULO R.S.T., 2012, Determinants of corporate debt maturity in South America: Do institutional quality and financial development matter?, in: Journal of Corporate Finance, 18 (4), p.15-23.

2. CHENG Y.P., 2012,Essential attributes of regional green competitiveness, in: Guangming Daily.

3. GUAN H.Q., QIN Y., DONG Z.F., 2016,The Latest Progress and Trend of China's Comprehensive Environmental and Economic Accounting, in: Environmental Protection Science, 42(2), p.22-28.

4. GUERRIERI P., MELICIANI V., 2005, Technology and international competitiveness: the interdependence between manufacturing and producer services, in: Structural change \& economic dynamics, 16(4), p.489-502.

5. GU S.Z., CAO D.M., YANG M., 2018, Strategic Thinking on Constructing the Innovation Ecosystem of Guangdong-Hong Kong-Macao Greater Bay Area, in: China Soft Science, 4, p.1-9.

6. HAFEZALKOTOB A., ZAMANI S. A., 2018, multiproduct green supply chain under government supervision with price and demand uncertainty, in: Journal of Industrial Engineering International, 3, p.1-14.

7. HOU C.A., 2015, Research on Evaluation of Green Competitiveness of Heilongjiang Equipment Manufacturing Industry, in: Harbin University of Science and Technology.

8. JOHN P., MASAHIRO A., 2004, Coherence and smoothing effects at a wind farm, in: Wing Energy, 7, p. $61-74$.

9. LI B.N., 2007, Fuzzy mathematics and its applications, in: Hefei University of Technology Press, p. 130-134.

10. LI L.S.,YANG C.H., LIU J., 2014, Research on Evaluation of Comprehensive Development Ability of Regional Manufacturing Industry in China - Empiri- cal Analysis Based on East, Mid and West Manufacturing, in: China Soft Science, 2, p. 121-129.

11. LI P.,WANG Q., HE J., WU B., 2010, Construction of China's Manufacturing Industry Sustainable Dedelopment Index System and Target Forecast, in: China Industrial Economics, 5, p. 5-15.

12. LI Y., ZHANG M., 2018, Green manufacturing and environmental productivity growth, in: Industrial Management \& Data Systems, 118(6), p. 1303-1319.

13. MARTINS A.A., MATA T.M., COSTA C.A.V., 2007, A framework for sustainability metrics, in: Industrial \& engineering chemistry research, 46(10), p. 2962-2973.

14. PORTER., 2011, A multi-factor efficiency to the relationships among the world GDP, in: Energy consumption and carbon dioxide emission, 73, p.87-89.

15. PORTER M E., CLASS V D L., 1995, Toward a new conception of the environment competitiveness relationship, in: Journal of Economic Perspectives, 9(4), p.97-118.

16. TAO J.C.,WU J.M.,2001, A New Probe into the Comprehensive Weight Determination of Comprehensive Weighted Scoring, in: Systems EngineeringTheory \& Practice, 8, p.43-48.

17. VACCARO A., 2010, Corporate transparency and green management, in: Journal of Business Ethics, 95, p. 487-506.

18. WANG L.,WANG R.,2010,Approaches to Enhance Green Competitiveness of Enterprises in a Low-Carbon Economy, in: Accounting Research,17, p. 5557.

19. WANG Y.M., 1998, Multi-indicator decision-making and ranking using dispersion maximization, in: China Soft Science, 3, p. 36-38.

20. YANG X.X., 2016, Research on China's Green Economy Competitiveness, Fujian Normal University.

21. ZHAI X.J.,2013, Research on the Construction of Green Innovation System of Heilongjiang Equipment Manufacturing Industry in the Low-carbon Era, in: Pioneering with Science\& Technology Monthly, 5, p. 12-15.

22. ZHOU S.J.,2015, Research on Influencing Factors of Green Competitiveness of Manufacturing Enterprises, Dalian University of Technology.

23. ZHU J., SUN X.Z., LIU X.M., SONG M., 2012, Research on China's Green Economy Strategy, in: China Population Resources and Environment, 22(4), p.712. 